\title{
Cultural Interpretation for Refugee Children: The Multicultural Liaison Program, Ottawa, Canada
}

\author{
Claudia Maria Vargas
}

\begin{abstract}
Cultural differences may pose as many challenges as linguistic difficulties for refugee children and theirfamilies in the school setting. This article explores the contributions of the Multicult ural Liaison Program (MLD) created by the Ottawa Board of Education and the Ottawa-Carleton Immigration Services Organization (OCISO). Through cultural mediation, the MLO Program builds partnerships that support the efforts of schools and the refugee communities they serve. Anchored in a systemic approach that considers the child, parents, the ethnocultural community, teachers, and school officials, the MLOs-or cultural interpreters-facilitate the learning and teaching processes.
\end{abstract}

\section{Précis}

Les différences culturelles sont susceptibles de poser autant de problemes queles difficultés linguistiques pourles enfants réfugiés et leur famille dans l'environnement scolaire. Le présent article examine les contributions du Programme de Liaison Multiculturelle (Multicultural Liaison Program:MLD) crééparleconseil scolaire d'Ottawa et l'Organisation des Services à l'Immigration de la région Ottawa-Carleton. Via la médiation culturelle, le programme MLO établit des partenariats qui épaulent les efforts des institutions scolaires et des communautés de réfugiés qu'elles desservent. S'appuyant sur une approche systémiquequi prend en compte l'enfant, les parents, la communauté ethno-culturellę, les ensei-

\footnotetext{
Claudia Maria Vargas, Ph.D., is Visiting Assistant Professor at the College of Educat ion and Social Seroices and Core Faculty of the Interdisciplinary Leadership Education for Health Professionals Program at the University of Vermont, Burlington, Vermont, USA.
}

gnants et les administrateurs scolaires, l'interprète culturel-MLO s'efforce de faciliter les processus d'apprentissageet d'enseignement.

\section{Introduction}

Host nations respond to increasing refugee populations in various ways. Someprovidemacro-level, comprehensive, government-funded service programs while others may do little to accommodate the refugees' complex needs and instead rely on micro-level programs provided bynon-governmental organizations (NGOs). Canada and Nordic countries use a hybrid approach, making resources such as housing, health insurance, and cultural interpretation available to children and their families through both governmental and NGO operations. However, in other countries, refugee children may not even get second language instruction, much less cultural interpretation to ease their adjustment to a hostsociety.

Unfortunately, linguistic and cultural misunderstandings have academic or educational consequences for children: "research has shown that children are the most vulnerable group, besides the elderly, to the stresses of migration" (Tam and Spigelblatt 1993). Miscommunication may occur among refugee children, teachers, school administrators, parents, and the community at large, leading to a loss of trust, a sense of alienation, and intensification of the sense of helplessness experienced by refugee children and their parents. Despite the well-understood reality that women and children need more assistance, they frequently receive inadequate help particularly in matters related to cultural interpretation and mediation (Camus-Jacques 1990; Martin 1995; Brown et al. 1996).

Refugee service providers buffer "cultural shock" to facilitate the experience of anew community in a novel way.
It is clear that schools are a key point where refugee issues, children, women, men and ethnocultural communities meet. Although the literature (SuarezOrozco 1989; Delgado-Gaitan and Trueba 1991;Boothby 1994; Farias 1994; Camino et al. 1994; Igoa 1995; Cummings 1996; Hyman et al. 1996; Yau 1996; Zhou and Bankston III 1998) recognizes that resolving cultural issues is critical to success for refugees in their new homes, the question remains: how can one design and implement an effective cultural mediation program that takes advantage of the special place and needs of school? This article examines a cultural mediation model, the Multicultural Liaison Program (MLO), which was born out of the need to address the cultural gap and takes advantage of the unique opportunities afforded in the school setting. The MLO Program, currently in operation in Ottawa, Canada, was developed to meet the needs of refugee children "to ease the transition for newcomer parents and children as well as teachers" (Tam and Spiegelblatt 1993, 3-4; see also Stambouli 1990).

A qualitative research approach consisting of semi-structured interviews of service providers, school principals, teachers, and multicultural liaison officers was used. School and classroom visits and attendance at parent and community meetings as a participantobserver supplemented the interviews. The research presented is part of a larger comparative study on refugee service delivery in various countries and several cities in the United States.

This article discusses and seeks to understand what has made the MLO Program so successful. More specifically, it suggests some of the key ways in which the program has used the school context as a base from which to build bridges that support both the efforts of the schools and the refugee communi- 
ties they serve. After such an examination, it becomes clear that culturalinterpretation (sometimes called cultural mediation) is central to the effective adjustment of refugee children to the school context and school expectations of the host country. It further suggests that cultural interpretation services need tobe based on a systemic approach that considers the child, the parents, community, teachers, and school officials. Such services can contribute to the well-being of all involved while facilitating learning and teaching processes.

The essay is organized in two parts. First, it describes the inception of the MLO Program and its various components. Second, it examines the impact of cultural interpretation on immigrant and refugee children, their parents, the community and on the school community.

\section{The Multicultural Liaison Program: Addressing Cultural Interpretation}

The Multicultural Liaison Program started as a project to meet the needs of refugee students identified by the Ottawa-Carleton Board of Education. In January 1991, the Board approached an NGO, the Ottawa-Carleton Immigration Services Organization (OCISO), to request help in dealing with issues that were emerging in schools with high numbers of immigrant and refugeechildren. ${ }^{1}$ Financing was shared equally. The project sought to engagejointefforts and capabilities of government and NGOs. The Board and OCISO worked together to create a pilot project that was launched in September 1991. Continued success led to the expansion of the project into an on-going program that grew from the initial three schools to a much larger effort currently covering two jurisdictions-the OttawaCarleton English Public Board and the French Public Board. While the MLO Program is based at 38 schools, it provides crisis intervention services to the entire Ottawa-Carleton school system, sometimes even to schools outside those jurisdictions.

\section{The MLO Program and Its Goals}

Initially, the project targeted three elementary schools and involved three full-time staff known as Multicultural Liaison Officers (MLOs). The MLOProgram had one objective in mind: to improve "communication between the schools and home." 2 Simple but effective efforts were implemented to bridge the gap between the refugee parents and school officials, including "making phone calls to the parents, translating notes for parents and teachers where there was a need for better communication between the two." ${ }^{3}$ The decision to employ a low-profile approach served two purposes: a) to establishMLOcredibility with teachers, parents, students, and the community; and b) to build trust among all involved. Both goals were achieved.

The initial group of MLOs understood several cultures and languages and could communicate effectively to share basic knowledge. The key was that, every MLOhad linguistic and cultural knowledge of some countries. Together, they had a great deal more, as exemplified by the MLOs' competence in 30 languages. By communicating with each other frequently, the MLOs could either provide the particular cultural competence required in a given situation or locate it through the effective network they had developed.

Although the project designers knew that MLOs could not remain "glorified messengers," this initial step was essential. Once trust and respect were established, the MLOs proceeded to address other objectives. Among these were efforts to: a) "assist immigrant students to adapt to their new environment and to benefit fully from the educational system; $b$ ) facilitate the involvement of parents in their children's education; and c) providecross-cultural sensitization training to the school staff" (Tam and Spigelblatt 1993). While these goals were articulated clearly, many of the school administrators and teachers involved truly did not know what to expect. Those interviewed reported uniformly that, although they initially had difficulty understanding what MLQs really were and what they would do, they now not only understand them very well but cannot understand how their schools functioned before MLOs came on board.

The MLOs work continually to find ways of fostering understanding of the school system and encouraging crosscultural sensitization for educators and students. It is a proactive rather than a reactiveprogram. Whilemuch of MLOs' work comes in response to calls for help from school staff, parents, and other MLOs, they also initiate projects and programs that seek to build understanding and avert problems before they manifest themselves. This is partly accomplished by helping Canadian students learn about diverse cultures and, in turn, help new arrivals learn about the host country's school system. Even so, the MLOs are often called to help resolve misunderstandings arising among students and parents due to differences in the school systems, i.e., that of the Canadian system and of the country of origin. In such situations, two major issues frequently emerge. First, how does the Canadian school system operate compared to that of the student's country of origin? Second, how do MLOs help students, parents, and teachers understand the cultural perceptions of teachers, parents, and women among the various ethnocultural groups represented?

For example, the Somalis, like people from a number of cultures, view teachers as authority figures and hold them in high regard. Somali mothers who are Muslim gienerally do not intervene in the education of their children, a role generally taken by males. ${ }^{4}$ However, the situation may become more awkward when Somali single or widowed mothers are faced with the need to deal with the schools on behalf of their children. This is an issue because "refugee families may break down within twoyears of arrival in the host country" or women were widowed as a result of civil strife in their homeland, as commonly occurred to Somali women. ${ }^{5}$ It is also an issuebecause Canadian culture seeks to enhance women's capability to play an equal and active role in society. Un- 
knowingly, teachers may question whether these mothers care about their children's education, a common misperception of refugee and immigrant parents, given their "reticence" to become involved (Nieto 1996; Hernandez 1997). On the other hand, Somali mothers may experience frustration at not being heard by school officials. In the end, the ones who really suffer are the children, who may find themselves with no one to mediate for their needs.

In such circumstances, MLOs have played a significant role. Thus, when it became known that Somali mothers were frustrated by a persistent problem with teachers of English as a second language (ESL), an MLO convened a meeting for Somali parents. She explained the process of communicating concerns to school officials. Concrete action was taken as the group worked together, with the facilitation of the MLO, to draft a letter to school officials. The most important outcome was notso much the letter but the empowerment experienced by the parents. The MLO had initiated a process of trust-building and communications enhancement through a discussion of common concerns identified by the parents as well as helping tolay foundations for constructive relationships between parents and educators in the Canadian context. Moreover, these mothers learned that it is acceptable for women to participate on an equal footing in school issues, and acquired some of the skills needed to do soeffectively.

\section{Improving Communication: An Essential Step}

This activity fits nicely into a key set of MLO priorities. That first task, to improve "communication between the school and the families of immigrant students" (Tam and Spigelblatt 1993, 4), requires time and effort. It demands a continuing investment of effort with an understanding that it may require some time before the fruits of that investment are evident. In order to do this, the director explained that MLOs "find excuses to get to know each other as persons." ${ }^{16}$ Establishing bridges of mutual trust and respect is always at the centre of the MLO work.

\section{Reaching Out to Parents}

The second priority was developing effective ways to reach out to parents, especially women, who may be alienated or intimidated by the school system. When parents come to school to pick up achild,MLOs are quick to tap theopportunity to chat. "I invite them for a cup of tea to my office. There was a Somali grandmother whojuststood outside the school in the cold. Since we could not communicate [linguistically], Ibrought her a chair for her to sit inside, an offer she accepted. ${ }^{17}$ Other ways of integrating parents into the school community were to "translate notices of meetings and important workshops," and "to contact families by phone, using the team of MLOs as interpreters."8

The toy library-another program originated by an MLO to help children as well as to attract parents to the school-operates with toys donated by children themselves. Those who want to borrow a toy can do so overnight. However, the projectneeded staffing. In this case, the contributions of the refugee community is exemplified by a "72year-old librarian who was afraid to come out of her house but now handles a toy library." This kind of reciprocity between the schools and the community enhances acceptance of diversity in societies maximizing the cultural and intellectual resources available among new arrivals: "exiled individuals and communities have contributed greatly to the cultural diversity and the intellectual vitality of their adopted countries" (UNHCR 1995, 17).

Helping parents to meet their responsibilities with schools and other agencies through the MLOs, without the need to rely on theirchildren, addressed another common problem in refugee families. When children become translators, they get into a dominant position relative to their parents, making parenting more difficult. Furthermore, ethical dilemmas are also avoided when MLOs, instead of students, translate for school officials and parents, thus averting possible violation of stu- dents' privacy (Haffner 1992; Vargas 1998). It also frees students' time and energy for participation in other school programs.

\section{Connecting School Staff and Parents}

Third, MLOs worked towards building closer contact between staff and parents of immigrant and refugee students. Explaining school regulations, in particular to single mothers with little or no literacy even in their native language (let alone English or French), was one way. "Parents are afraid even to talk to the secretary of the school. When their children are sick they are afraid to call the school to notify them of it," but with the efforts of MLOs, teachers "became more understanding" and learned "not to make assumptions, and instead to find out ${ }^{\prime \prime 9}$ what was really taking place. In cases where the way of doing business did not recognize the parents' needs, school procedures were changed. For instance, "the process for parent teacher interviews [were modified] to allow time for interpretation and some flexibility in scheduling, ${ }^{\prime 10}$ as meetings with students and their families are now arranged by the MLOs.

\section{Facilitating Access to Community Resources}

A fourth objective of the project was "to connect the students and their families to other appropriate resources in the community" (Tam and Spigelblatt 1993, 4). MLOs call on other agencies to help parents with resettlement or housing arrangements and assist them in accessing crisis intervention services for run-away youths. "Information sessions on topics of interest" are provided by the MLOs themselves or by representatives from pertinent "agencies such as the YMCA, heritage language schools, United Way, or health centres." 11

\section{Maximizing School Resources}

Another objective of the program is to use school resources more effectively. If MLOs can do the workneeded to bridge the goals of teachers and parents for the children by mediating between the 
school and the home, "teachers can focus on teaching according to the needs of students."12 For example, report cards have been translated and simplified to accommodate the needs of parents. With the assistance of MLOs, parents can now communicate to teachers and school officials their "educational aspirations and expectations" for their children. This support has turned one of the most forbidding parental obligations, parent-teacher conferences, into positive experiences for many refugee families.

\section{Educating about Specialized Services}

Finally, "the MLOs link parents and students to appropriate services that may be required to facilitate learning" (Tam and Spigelblatt 1993,4). Access to services becomes easier when the MLOs "precede referrals with phone calls," given that, for example, psychological interventions with refugees are more complex (Chester and Holtan 1992). This kind of communication among service providers, the schools, and the clients is possible due to the "close collaboration that MLOs maintain with other service providers." 13 In some cases, services may be necessary to help refugee children with health problems including Post-Traumatic Stress Disor$\operatorname{der}(\mathrm{PTSD}){ }^{14}$ which may go undetected by teachers but in fact seriously affects learning (Chester and Holtan 1992; Lavadenz 1994, Hyman et al. 1996). MLOs can easily intervene when PTSD issues are at stake or vaccinations are required.

\section{Results to Date of MLO Efforts}

The Multicultural Liaison Program has been rated very positively by teachers, principals, parents, and the community. Specific results include increased "participation in parent/teacher interviews, which went from almost nonexistent to at least 60 percent" (Tam and Spigelblatt 1993,4). Parents who stayed away from schools either because of distrust of the schools or to language difficulties "have started to call the school and request meetings with teachers. This did not happen before, except in 'critical' circumstances." 15 As a Vietnamese MLO elaborated, "Parents still call me for help five or six years later, even after they have moved to other areas." 16 The interactions have changed as stakeholders, parents, students, and educators "collaborate in the decisions about the students' education." MLOs also maximize parents' visits to the schools "to do 'on the spot' needs assessments and referrals."17

The Multicultural Liaison Program's interventions for the immigrant children, their parents, the community, and school officials have resolved a great deal of the ambivalence and confusion because trust has erased past miscommunications. Essential cultural modulation allows teachers to get on with the business of teaching, helps children understand cultural differences so that they can focus on learning, and parents and the community communicate their care and concern to educators, critical to healthy integration of child refugees.

\section{Breaking Down "Non-Academic Barriers" through Partnerships}

Educators can learn a number of lessons from a study of this approach to serving the needs of refugee children. The lessons, affective and cognitive, include: (1) awareness of who the refugee service providers are; (2) enhanced understanding of the needs refugee children have in the educational setting; (3) a clearer recognition of the "non-academic barriers"18 that must be addressed if the children are to progress; (4) heightened sensitivity to the importance of integrating parents and their community into the school community; and (5) greater sensitivity to the importance of decreasing racial and ethnic tensions that may be introduced to school by the children.

\section{Who Becomes a Refugee Service Provider? What Does It Take?}

Many refugee service providers are themselves former refugees or members of refugee families. They frequently operate in a pressure-filled, resource-poor environment, often with a high turnover and burnout rate, all characteristics common of educators. An indication of awareness of specific problems in their work is helpful to understand how MLOs foster respect and build trust (Vargas 1998). A female principal attributes the success of the MLOs to the various factors:

Issues of heart are difficult to translate, if you have only knowledge of the language, but MLOs are able to convey deep thoughts; it's more than just translation. It is also intimidating to reach out to the community from the school office. Therefore, we have to do outreach through the MLOs.

However, the rate of success of the MLO is determined by the personality and initiative of the MLO. Some MLOs have a "sit-and-wait" approach while others have a very proactive one, and have a great deal of initiative to begin new projects. Our current MLO knows exactly what you need. She also knows her colleagues very well and knows how to match the right individual to the situation, whether it is a gender issue, [or] a personality issue. In other words, it is not just a linguistic issue. The school also bears responsibility for the success of the MLOs. They need to have their own telephone lines and answering machines since families will latch on for a long time. MLOs need to feel part of the school staff, and this will depend on how well they are introduced to the staff. We connect them to the internal email system. ${ }^{19}$

The MLOs build on their personal refugee experience to deepen understanding of, and empathy for, new arrivals. Their commitment to help refugees is both to ease cultural shock and to contribute to their host country, Canada. Although this implies more than a nine-to-five job, the MLOs draw on their painful and traumatic refugee past to extend themselves to others. In one of the interviews with female refugee service providers with whom the researcher had been working for a period of over fouryears, the women found themselves reliving the experience of flight as the long-repressed memories gushed out unexpectedly. One shared for the first time the story of her family's flight out of Vietnam and the boatjour- 
ney they hoped would take them to a safe but unknown destination. Later, after arriving in Canada, she recalled the recurrentnightmare of being sea sick long after the ordeal and memories of the fear of sea pirates.

Experienced at building a network of culturalbrokers, MLOs maximize talent and scarce resources:

Even though not originally conceived as a role for the MLOs, they are now doing more and more counselling. The hope is that there will be an MLO at every school. The MLOs work closely with the guidance faculty and the vice-principal. In fact, the counselling office often refers cases to the MLOs, who then proceed to deal with situations. Since students discuss parental demands-or expressions of concern for the general welfare of their parents who may be out of work-with the counsellors, the MLO is called upon to follow up, because the MLO network can facilitate intervening with partents, or even helping parents find jobs. ${ }^{20}$

Thus, MLOs find ways to match the needs of the refugee child and family with resources: "the contact of the MLO is beyond the school, because of what kids say in counselling." ${ }^{21}$ As MLOs themselves endured anomie, a dramatic change in status or loss of prestige, or a loss of professional opportunities upon their arrival, they now reachyout to others.

\section{The Needs of Refugee Children}

The Multicultural Liaison Program has been regarded as highly successful by teachers, principals, school board members, and the communities it serves inits support of immigrant children. One of the lessons from the MLOProgram concerns the fact that, because of developmental issues, refugee children and adolescents bring to school a different cognitive, affective, and psychological profile from other students. Furthermore, their school needs are dynamic depending on who the most recent refugee groups are. In this instande, the MLO Program continues to change in order to respond to the needs of newi arrivals.

Another lesson concerns assessment. Assessment and proper place- mentconducted in the native language, as is done in Ottawa, has served the children well and has also made the teachers' job easier. This type of assessment is particularly important for children with learning or neurodevelopmental disabilities or children who have not had the opportunity to develop literacy and numeracy skills. However, assessment of children with special needs still poses additional challenges. Informal assessment is done with the help of the MLOs in the native language when $I Q$ testing and possible referral to special education issues emerge.

\section{Children with Special Needs}

Cultural interventions become more critical when refugee children suffer from neurodevelopmental disorders, and may even lack a native language in which to communicate. In Ottawa, an MLO intervened in a case in which "the school officials were frustrated with a girl who was hearing impaired and was not advancing in her school work." She decided to visit the family at home. In meeting with them, family members assured her that in fact they were helping the daughter with school assignments. The experienced MLO then proceeded to ask the parents:

When you show her an apple, what do you say?" The parents quickly responded with the proper word.

However, they were using both Persian and a Kurdish dialect in helping the child. At this point, I told them that they needed to practice the lesson in English because this was creating confusion for the child at school. ${ }^{22}$

The lesson learned from this incident is that, although the parents were being supportive of school efforts, there was a misunderstanding.

In another case, a hearing impaired child was provided with an augmentative hearing device (AHD) at school. At home, the child became frustrated and anxious. Since the family spoke no English, the MLO got involved. Other professionals also got involved, thinking that the problems were medically related. However, after extensive testing, the professionals did not find anything wrong beyond the original diagnosis. The problem was one of communication in four areas. First, the parents were operating from the cultural premise that the teacher was the expert. Second, the teacher did not call the family because they did not speak English. Third, the parents were worried that if the child was becoming mentally ill, it was going to be advertised to the school and the ethnic community. Fourth, for someethnic groups, the family doctor is the expert. ${ }^{23}$ Thus, rather than request a referral to a specialist, they continue to take the child back to the family physician. In fact, they may not even understand the concept of "specialist" doctors. Even though the MLO's intervention identified the source of the problem-that the child was not allowed to take the AHD home, causing her great frustration-theschool still did not provide for its use beyond school grounds. These cases indicate the need for a family-centred and culturally-sensitive approach advocated and modelled by the MLOs.

Another aspect of refugee children's psycho-social development is taken into consideration when cultural interpreters are available in Canada to avert possible traumatic experiences. For example, in some cases refugee children's games and style of playing has been interpreted by school officials as "too aggressive" or misinterpreted as "fighting." However, when a principal in a Canadian school called two boys who were assumed to be fighting, the children responded as they hugged each other, "We were not fighting! We are friends!"24 In similar situations, the MLOs continue to sensitize school personnel. Unfortunately, ethnic conflicts are sometimes transplanted to host nations, creating dilemmas for teachers and school administrators.

Through the interventions of the MLOs, consideration has been given to the children's needs regarding religious practices. In the case of Muslim children who fast for Ramadan, school rules that required them to be in the cafeteria became very difficult. To accommodate their religious observance, some school administrators opened a game 
room during lunch period. Thus, "Muslim children could engage in educational games that entertained them instead of dealing with the temptation of eating when fasting." ${ }^{25}$ Other principals interviewed accommodated the needs of Muslim students who pray.

The school found a room for them. The school requests a parent's note granting permission for their children to be excused from class for a half hour every Friday. Since the children have to do a thorough cleaning of their bodies before prayer, the MLO has helped to accommodate their needs. ${ }^{26}$

Adolescent refugees face another set of problems in an already difficult developmental stage which is intensified by the refugee experience. Cultural interpreters, who interact with schools, parents, social agencies, and even police on teenagers behalf, deflect a great deal of conflict for teenagers. The MLO Program clearly indicates that developmental tensions are significantly worse for adolescents, since refugee children are under additional stressors imposed by flight and, in some cases, torture and abuse.

Dating issues, so critical for teenagers, often create cultural conflict at home, in the schools, and with the community. Teenage refugees find in MLOs "a friend," someone in whom they can have trust and who will listen to them. "Students find it reassuring to know that there is someone who understands the problems they face." 27 Students have benefited from counselling provided by bicultural counsellors or an MLO appointed by the board of education as a mental health worker. For parents, cultural interpreters organize conflict resolution workshops, classes about the host culture, and Parent Discussion Groups.

With regard to education, refugee students have been empowered. In cultural interpreters they find a listening ear and a person who understands their culture but is there to mediate for them when academic problems emerge. Not only are cultural workers positive role models for them, they also help "students realize MLOs are willing to help them find solutions. ${ }^{28}$ For example, curricular goals that conflict with gender roles and religious beliefs have been mediated by cultural interpreters. Muslim girls who cannot wear sports clothes because of religious restrictions havebeen allowed to substitute computer classes for physical education. ${ }^{29}$

Culturally-affirming programs such as the MLO Program serve dual functions. First, cultural mediation fills a gapbetween thestudents' privateworld and school expectations that can clear the way for academic achievement. "It instills students with confidence in the school system." ${ }^{30}$ Second, possible disengagement due to "cultural discontinuity" is averted, when refugee students' energies are channelled into setting up cultural youth groups, participating in heritage schools or participating in the foreign language program in which immigrant and refugee children teach their Canadian peers their native languages and cultures (discussed later) (Olneck 1994, 325). These activities foster and strengthen cultural identity while having a positive impact on students' academic performance. The academic environment is thus enhanced when students and teachers, through mediation by the MLOs, understand each other's meanings and symbols mediated by the MLOs.

\section{Breaking Down Non-Academic Barriers in the Schools}

School officials and educators often have the best intentions at heart, but may lack knowledge of the cultural ramifications of applying normal school procedures and rules to refugee children. Even when language translation is available, the cultural dimension may be overlooked, creating unnecessary tensions. As an elementary school principal from the Ottawa area stated, "Translation of words isn't enough. MLOs understand both the cultures and the school system." Further, as MLOs have indicated, "we don't take sides. We listen to both school officials and the parents, and try to help them understand each other's concerns. ${ }^{131}$ According to a school administrator, MLOs "are excellent notjust with literal trans- lation but with nuances of cultural differences, ${ }^{\prime 32}$ especially when curricular issues are at stake. In fact,

some curricular expectations may pose a potential conflict with religious or cultural traditions. For example, Muslims are not allowed to dissect frogs, therefore we have accommodated by providing computer programs that have simulations of the same procedure. Or we make teachers aware of the demands of Ramadan on the children. Teachers can then be sensitive to the effects of fasting on the children who may be more tired or irritable. ${ }^{33}$

Interventions by cultural brokers lessen the stress on teachers while supporting "culturally responsive instruction" (Olneck 1994, 325). Since academic expectations or pedagogical appropriateness may need cultural mediation, school support of MLOs as equal parthers in school endeavours is critical. Schools should give MLOs access to e-mail.

E-mail makes it easy to consult with MLOs. For example, a teacher contacted an MLO for the following: "I will be teaching an unit next week, but a student says there is a feast and he can't participate." Or male Muslim students may object to working in coed groups in a science class, or ninth graders have objected to participating in mixed groups in physical education classes. The student makes the request, but we consult with the MLO. If the MLOendorses it, teachers respect it ${ }^{34}$

When teachers are able to understand that gender makes a difference when dealing with Somali boys, and that an overgeneralization that all "Vietnamese refugee children come with excellent academic skills" is just that, they can move on to meet the individual needs of new arrivals. Let us consider this example:

A teacher complained to me [to the MLO] abiout the unusual behaviour of some of the newly-arrived Vietnamese students who were doing poorly academically. In particular, a boy pushed to be first in line for everything. Although there were plenty of pencils and crayons on every desk, he would take them and hoard them 
in his desk. He did not take them home. He also displayed other aggressive behaviours towards his classmates. $^{35}$

The cultural interpreter was herself a Vietnamese refugee who had also worked through the United Nations in refugee camps in Hong Kong. She explained to the Canadian teachers that

these children had to learn [in the camp] that in order to get food, they had to push their way around and be first in line, otherwise they went unfed for the rest of the day because of food shortages. Many had not had schooling because it was unavailable in the camps. ${ }^{36}$

In this case, the cultural interpreter helped teachers deal with other nonacademic issues that may affect the classroom experience. Consider the case of a mother whose daughter wanted to marry outside her ethnic group.

In one of the Parent Discussion Group meetings, the mother had shared that she had told her husband she would not tolerate his hitting her children anymore. On one occasion, the daughter asked us [school officials] to be excused from an exam because of stress; she even had a doctor's note. This story seemed fishy to us, so we checked her record of lates and absences, only to discover that she had forged her mother's signature in 28 notes. We called the mother to discuss this. It turned out that since she [the daughter] was not allowed to see the guy, she was doing it during school time. Had the mother not been to the discussion groups, where she could see us as her allies, this wouldn't have felt comfortable to approach. The situation had a happy resolution through the intervention of the MLO. The girl is now allowed to see the young man. ${ }^{37}$

Issues of confidentiality are resolved when cultural interpreters are available at schools. Previously, schools have had to rely on children, creating ethical problems. On the one hand, negative effects commonly encountered when children are used as translators include: a compromise of confidentiality; lying about grades by the children; and the inability of the children to handle diffi- cult emotional and linguistic situations. ${ }^{38}$ On the other hand, school volunteers from the ethnocommunities may present problems, too. Issues of confidentiality may emerge when schools rely on these volunteers since they may know the family involved (Vargas 1998). ${ }^{39}$ However, cultural interpreters who have earned the trust of the community have played a crucial role in averting these ethical dilemmas. The role of the MLO was central in a thorny situation: "We had to notify a mother about the accident her son had been in. Instead of calling her on the phone, we sent the MLO to tell her in person. Because contact had been preestablished, this was much easier to handle. ${ }^{\prime 40}$ Because a working relationship had been developed with the mother, it was easier to break the bad news. Calling on a student to translate for school officials would have been ethically problematic, because of family privacy issues and because it would have placed another child in an emotionally stressful situation.

In other cases, cultural interpreters help teachers learn about the importance of cultural traditions that children bring to schools. In this manner, teachers deal with cultural differences that may impedelearning. Regardless of the specific situation, the work of cultural brokers represents major strides in the adjustment of refugee children in the schools. Teachers spend less time on non-educational problems, which according to a respondent, "Allows us to spend more time on the job we were trained to do." ${ }^{\prime 41}$ Another educator commented, "we treat people better," resulting in improved relations with parents and the community. ${ }^{42}$

\section{Bridging the Parents and the Community with the School Community}

The MLO program has been successful at building bridges between parents and other community members and the school community. Furthermore, the participation of parents and community membershas a positive effect on the students and the school community (Nieto 1996; Tam and Spigelblatt 1993;
Gandara 1995). The task of including refugee groups in the broader community may beoverwhelming due tocrosscultural barriers. The MLO Program uses a "reach-out" approach before engaging in actual community organizing. The positive effect of the reach-out approach of the Multicultural Program on the children, the parents, the community, the teachers, and other school officials has been multiple. Although a common occurrence, police presence in the schools can trigger fear among refugees. Through the Parent Discussion Groups, the perception of police presence in the schools has been turned around.

One issue that came up was the police presence in the school, because we have a police resource officer assigned to each school. Given that refugees have endured persecution by authorities in their homeland, when the children see a police car parked outside the school, they become alarmed. However, the officers are here to deal with safety issues, places to avoid and to alert them to certain parts of town. Other subjects covered by the officers is drug awareness educational programs. Since the officers sometimes are in uniform, the children responded with fear. These sessions have helped the parents and the children understand the officers' role. Consequently, the children have learned that it is all right to approach the officers. ${ }^{43}$

The MLOProgram has afforded parents with critical system skills and knowledge how the school system works in Canada. "When parents understand the grading system, they can take a more active role in the progress their children are making." 44 The Parent Discussion Groups, created by an MLO, have been instrumental is communicating with school officials these kinds of concerns. At these meetings,

We explain the Canadian school system, the general and advanced components or the academic versus applied courses. We also discuss marking (grading) procedures. Since there is a 40-hour community service requirement, we explore with the parents appropriate placements for 
their children. For example, we discuss the needs in their communities, and linguistic considerations. The parents will share with us information on the [ethnocultural] organizations to which they belong, and request that their children do the community service requirement at one of them. This is helpful, because the organizations are based in their own communities solving transportation problems for the students. ${ }^{45}$

As parents learn more about the educational process of the host country and find a space in the school community, "they feel comfortable about volunteering at school and about participating in advisory council meetings."

\section{Towards a Multicultural Society: Decreasing Racial Tensions}

The contribution of cultural interpreters in addressing racial tensions in the schools has been attested to be critical. In Canada, the Multicultural Law was instituted in 1988 (Elliot and Fleras 1992). Regardless of the approach, laws need to translate into specific programs. In this respect, the MLO Program has been instrumental in building bridges across various ethnic groups and across ethnic groups and Canadian students. Specifically, racial and "cultural teasing" has been addressed by MLOs while facilitating a healthy integration of refugees into society. ${ }^{46}$

In many instances, not only have cultural interpreters deflected possible escalating conflict, but they have worked towards creating racial tolerance. The principal of a high school acquiesced with the perception of other principals:

There has been a definite difference in the school since the MLOjoined the school. In fact, within three months of her arrival, we were racial-conflict free. We have not had a single incident since then [one-and-a-half years old]. She is very artful at working with the students and the teachers. My colleague, who took over a school that was most problematic, has been able to turn the school around completely with the help of the MLO. ${ }^{47}$

MLOs step in todiffuse conflict, even when racial tensions are caused by stu- dents dating outside of their own ethnic group, or when conflict is due to imported tribal feuds. Cooperative efforts, such as the foreign language program or the cultural celebration activities, have been established with Canadian students to ease racial strain provoked by attitudes towards refugee and immigrant students. Specifically, ethnic, racial, and "cultural teasing" have been channelled into increased cultural awareness and acceptance of diversity, although much remains to be done given a recent assault on a Muslim student. ${ }^{48}$

\section{Foreign Language Program: Planting the Seed of Diversity}

Responding to the need to entertain children at lunch time during the frigid winter, an MLO developed the foreign language program at an elementary school. It consists of children teaching their native languages in 20-minute periods during lunch for a 10 -week session. The languages arenon-Western or nontraditional, such as Farsi, Arabic, Somali, Polish, Turkish, and others. Children volunteer to be "teachers." These children come into class with their portfolios of prepared lessons. Not only do they teach oral skills, but they also work on writing skills. Most impressive yet, their lessons include a strong cultural component. When asked to say what they liked about the program, children's responses were: "I get to learn a new language;" "we can speak with other people;" we get to do fun things and have a good time;" "it's fun to learn different things from around the world;" "if new people come [to school] we can speak to them;" "we're learning how other people communicate;" "it's easier to learn a language from another student;" and "we don't get put down and we don't get laughed at when we make a mistake." 49

Observations of these student-teachers indicated that they, intuitively, are doing what current research on second language acquisition recommends: respecting the silent period, asking questions to assess learning, lowering the affective filter or having "fun" ("It's like playing!"), integrating listening, speak- ing, reading, and writing skills, using mistakes as opportunities for learning ("If we make a mistake, he tells us to try again!"), and teaching language in context ("they tell stories") (RichardAmato 1996;Omaggio 1993; Oller 1993; Krashen 1985; Krashen and Terrell 1993). One of the child-teachers indicated that, "If you make them feelit's OK to make mistakes, they try again." Visually-rich and contextualized teaching materials, are created by the child-teachers themselves. Some of the illustrations with writing, tell stories. ${ }^{50}$ The success of the program was such that ithas been introduced to 11 other schools. Among the many features of the MLOprogram, the foreign language classes stands out as one that truly builds bridges among Canadian, refugee and immigrant children.

\section{Celebrating Cultures}

Another significant activity of the MLO is organizing cultural celebrations. Ata high school, an MLO organized a comparative religion session entitled, "Christianity, Islam, and Judaism: A Comparative Study," in which a rabbi, a pastor, and a representative of the Muslin religion discussed the pillars of each faith. 51 At another high school, a similar activity was conducted with student representatives of each religion. "After each student talked about his or her religion, we asked them about commonalities among all. ${ }^{52}$

Schools, the community, teachers and students have joined hands to celebrate cultural diversity. Celebration of multicultural week, and regular workshops for school personnel and for students have become part of the schools operation. The MLOs provide multicultural training for school personnel and organize the Multicultural Celebration WeekFairs for students and parents in which at least 16 cultures are introduced through 25-minute presentations by representatives of those cultures. Multicultural dinners renamed "International Dinner" in order to attract participation of Canadians have become a qommon practice at schools to bring schools and community members closer together. 
Possible cultural collisions are certainly averted when refugees are allowed to retain their native language. The benefits of preserving ethnic groups at the local level are twofolid. First, the ethnic group can evade harm from assimilation or "cultural discontinuity" (Olneck 1994, 325) in which the native culture is surrendered. Second, they enrich the communities where they resettle with their cultural, intellectual, and linguistic heritage, e.g., when refugee children teach their languages to Canadian children through the Foreign Language Program.

\section{Conclusion}

Cultural interpretation services based on a systemic approach that considers the child, the parents, community, teachers, and school officials contribute to the well-being of all involved. The lessons learned from this kind of study of a model of cultural mediation can contribute to the building of partnerships among the schools, the community, and other social service agencies who serve refugees. An essential ingredient of this program has been the consistent efforts of cultural interpreters towards building trust among students, parents, teachers, school administrators, and the community at large. This goal has been achieved through small efforts, from translating for Somali mothers with limited literacy to explaining school rules and regulations to children and parents, taking parents to doctor's appointments, mediating between teachers and students about possible misreading of academic objectives, developing foreign language programs taught by refugeechildren, etc. A principal stated that, it [the interventions of the MLO Program] leaves the door open for children to get on with their learning and teachers to focus on teaching." An MLO portrayed it as "a puzzle that comes together."53

The Multicultural Liaison Program offers hope in addressing these needs which can only occur when communities are committed to, and supportive of, pluralistic societies. Although this has been a solid program, it still faces pressures due to funding cuts toNGOs and schools. Although expansion has been a positive force, it also demands more effort to maintain the network and cohesion that promotes success. The complexity of changes in funding for both NGOs (Herman 1994) and schools may undermine the work of both, if ministers and local officials are not alert and sensitive. These threats need to be addressed in greater detail, since it is clear that the government/NGO partnerships are becoming more complexevery day (Weisbrod 1997). Notwithstanding these concerns, the MLO program provides an important model for action.

\section{Notes}

1. Interviews with MLO Director, Ottawa, Canada, November 1993, February and April 1994; personal communications, January 1996; conversations, August and December 1996, April 1997, April 1998.

2. Interview with Multicultural Liaison Project Director on February 7, 1994, Ottawa, Canada.

3. Ibid.

4. Interview with MLO Director and two MLOs from Somalia, Ottawa, Canada, November 1993, February 1994, and April 1994.

5. OCISO Interviews with Community Development Workers, Social Workers, MLO Program Director, February 1994, Ottawa, Canada.

6. Interviews with the MLO Program Director, Ottawa, Canada.

7. Personal communication with MLO, April 1998.

8. Interview, MLO Director, April 1994, Ottawa, Canada.

9. Interview with MLO fluent in both Vietnamese and Chinese, February, 1994, Ottawa, Canada.

10. Interview, MLO Director, April 1994, Ottawa, Canada.

11. Ibid.

12. Interview with the principal of Elementary School No. 1, February 1994, Ottawa, Canada.

13. Interview with MLODirector, April 1994, Ottawa, Canada.

14. Physical, emotional, and cognitive manifestations of PTSD: loss of interest in ageappropriate activities, listlessness, concentration difficulties, daydreaming during class, aggressive or regressive behaviour (e.g., bedwetting), restlessness, detachment from others, intrusive images and flashbacks, bitterness, fear of particu- larnoises [helicopters flying over], depression, and irritability.

15. Interview with MLO Director, April 1994, Ottawa, Canada.

16. Personal communication with MLO, October 1998.

17. Interviews with MLO Director and several MLOs, April 1994.

18. This is how the principal of High School No. 1 conceptualized the work of the MLOs, interview, April 1994, Ottawa, Canada.

19. Interview with the principal of High School No. 4, December 1998.

20. Interview with theprincipal of High School No. 4, December 1998.

21. Ibid.

22. Presentation by three MLOs, Vermont Interdisciplinary Leadership Education for Health Professionals Program (VTILEHP), University of Vermont, October 1998.

23. Ibid.

24. Interview with the principal and vice-principal of Elementary School No. 2 in the Ottawa-Carleton area, April 1994, Ottawa, Canada.

25. Interview of MLO, Ottawa, Canada, April 1994.

26. Interview with theprincipal of High School No. 4, December 1998.

27. Interview with MLO who speaks seven languages, April 1994.

28. Interview with Principal, High School No. 4, December 1998.

29. Interviews with the principal of High School No. 2, and Somali MLO assigned to it, Ottawa, Canada, April 1994.

30. Interview with the principal, High School No. 4, December 1998.

31. Personal conversation, three MLOs, October 1998.

32. According to the principal of Elementary School No. 1 which had 47-50 percentEnglish as a Second Language students, February, 1994, Ottawa, Canada.

33. Interview with the principal of High School No. 4, December 1998.

34. Ibid.

35. Interview with MLO, Ottawa, Canada, April, 1994.

36. Ibid.

37. Interview with principal, High SchoolNo. 4, December 1998.

38. For an excellent discussion of a cross-cultural misunderstanding in the health arena and the importance of cultural brokers, see Anne Fadiman, The Spirit Catches and You Fall Down: A Hmong Child, Her American Doctors, and the Collision of Two Cultures, 
(New York: Farrar, Straus and Giroux, 1997).

39. Telephone conversation with MLODirector, January and April, 1996.

40. Interview with the principal of High School No. 4, December 1998.

41. Interview with the principal of elementary school Elementary School No. 2, April, 1994, Ottawa, Canada.

42. Interview with the vice-principal of Elementary School No. 2, April 1994, Ottawa, Canada.

43. Interview with the principal of High School No. 4, December 1998.

44. Sonia Nieto discusses this at length in her book, Affirming Diversity. In the book's case studies, what becomes clear is that parents from diverse ethnic or racial or cultural background indeed care about the education of their children, even when they arenot actively involved with the school, or when parents do not have any communication with school officials.

45. Interview with the principal of High School No. 4, December 1998.

46. Interviews with various MLOs, attendance of Multicultural Week Celebration, and interviews with school administrators, November 1993, February 1994, Ottawa, Canada.

47. Principal at High School No. 3, Ottawa, Canada, November 1998.

48. A Somali female high school student was assaulted by her classmates right after school and outside school after continuous racial teasing and singling out. She was the only Black student in the school. The assault was so severe that she is at risk of losing a kidney and other possible consequences, January 1998.

49. Classroom observations at elementary school Elementary School No. 2, Ottawa Canada, June 1997.

50. Ibid.

51. Meeting at High School No. 3, Ottawa, Canada, November 1998.

52. Interview with the principal of High School No. 4, December 1998

53. An MLO from the Middle East, fluent in seven languages, described the role of the MLOs in this manner.

\section{Bibliography}

Boothby, Neil. 1994. "Trauma and Violence among Refugee Children." In Amidst Peril and Pain: The Mental Healthand Well-Being of the World's Refugees, edited by Anthony J. Marsella, Thomas Bornemann, Solvig Ekblad, and John Orley, 239-59. Washing- ton, DC: American Psychological Association.

Brown, Lester R., Christopher Flavin, and Hal Kane. 1996. Vital Signs 1996: The Trends That Are Shaping our Future. New York/ London: W.W. Norton \& Company.

Camino, Linda A., and Ruth M. Krulfeld, eds. 1994. Reconstructing Lives, Recapturing Meaning: Refugee Identity, Gender and Culture Change. Australia: Gordon and Breach Publishers.

Camus-Jacques, Genevieve. 1990. "Refugee Women: The Forgotten Majority." In Refugees and International Relations, edited by Gil Loescher and Laila Monahan, 141-57. Oxford: Clarendon Press.

Chester, Barbara, and Neal Holtan. 1992 "Working With Refugee Survivors of Torture." Western Journal of Medicine, no.157, 301-4.

Crawford, Jim. 1992. Hold Your Tongue: Bilingualism and the Politics of English Only. Reading, MA: Addison-Wesley.

Cummins, Jim. 1996. "Negotiating Identities in the Classroom." Multicultural Teaching 15 , no. $1,7-11$.

Delgado-Gaitan, Concha, and Henry $T$. Trueba. 1991. Crossing Cultural Borders: Education for Immigrant Families in America. London: Palmer Press.

Diaz Soto, Lourdes. 1997. Language, Culture, and Power: Bilingual Families and the Strugglefor Quality Education. Albany, NY:State University of New York Press.

Elliot, Jean Leonard, and Augie Fleras. 1992. Unequal Relations: An Introduction to Race and Ethnic Dynamics in Canada. Scarborough, ON: Prentice-Hall Canada Inc.

Fadiman, Anne. 1997. The Spirit Catches and You Fall Down: A Hmong Child, Her American Doctors, and the Collision of Two Cultures. New York: Farrar, Straus and Giroux.

Farias, Pablo. 1994. "Central and South American Refugees: Some Mental Health Challenges." In Amidst Peril and Pain: The Mental Health and Well-Being of the World's Refugees, edited by Anthony J. Marsella, Thomas Bornemann, Solvig Ekblad, and John Orley. Washington, DC: American Psychological Association.

Gandara, Patricia. 1995. Over the Ivy Walls: The Educational Mobility of Low-Income Chicanos. Albany, NY: State University of New York Press.

Haffner, Linda. 1992. "Translation Is Not Enough:Interpreting in a Medical Setting." Western Journal of Medicine 157, no. 3, 21559.

Herman, Robert D. and Associates. 1994. The Jossey-Bass Handbook of Nonprofit Leader- ship and Management. San Francisco: Jossey-Bass Publishers.

Hernandez, Hilda. 1997. Teaching in Multilingual Classnooms: A Teacher's Guide to Context, Process, and Content. Upper Saddle River, NJ:Prentice-Hall

Hyman, Ilene, Morton Beiser, and Nhi Vu. 1996. "The Mental Health of RefugeeChildren in Canada." Refuge 15, no. 5, 4-8.

Igoa, Cristina. 1995. The Inner World of the Immigrant Child. New York, NY: St. Martin's Press.

Krashen, Stephen. 1985. The Input Hypothesis: Issues and Implications. London: Longman.

Krashen, Stephen, and Tracy Terrell. 1993. The Natural Approach: Language Acquisition in the Classrobm. New York: Pergamon Press.

Lavadenz, Magaly. 1994. "The Effects of War Trauma on Central American Immigrant Children." In Education in Urban Areas: Cross-National Dimensions, edited by Nelly P. Stromquist, 219-35. Westport, Connecticut, London: Praeger.

Leavitt, Lewis A., and Nathan A. Fox, eds. 1993. The Psychological Effects of War and Violence on Children. Hillsdale, NJ: Lawrence Erlbaum Associates, Publishers.

Martin, Susan Forbes. 1995. Refugee Women. London \& New Jersey: Zed Books Ltd.

Nieto, Sonia. 1996. Affirming Diversity: The Sociopolitical Context of Multicultural Education. $2 \mathrm{~d}$ ed. White Plains, NY: Longman Publishers USA.

Oller, John W. 1993. Methods That Work: Ideas for Literacy and Language Teachers. $2 \mathrm{~d}$ ed. Boston, MA: Heinle \& Heinle Publishers.

Olneck, Michael R. 1994. "Immigrants and Education." In Handbook of Research on Multicultural Education, edited by James A. Bank and Cherry A. McGee Banks. New York, NY: Macmillan Publishing Company.

Omaggio Hadley, Alice. 1993. Teaching Language in Context. 2d ed. Boston, MA: Heinle \& Heinle Publishers.

Richard-Amato, Patricia A. 1996. Making It Happen: Interaction in the Second Language Classroom: From Theory to Practice. $2 \mathrm{~d}$ ed. White Plains, NY: Longman Publishing Group.

Sleeter, Christine E. 1991. Empowerment Through Multicultural Education. Albany, NY: State University of New York Press.

Stambouli, F, 1990. "Born Underprivileged." World Health, March Issue, 3bw, 6-9.

Suarez-Orozco, Marcelo M. 1989. Central American Refugees and U.S. High Schools: A Psychosocial Study of Motivation and Achievement. Stanford, CA: Stanford University Press. 
Tam, Moy and Lucila Spigelblatt. 1993. "The Multicultural Liaison Project: An Innovative Partnership Working with Children." In International Settlement Canada Research Resource Division of Refugees (INSCAN) 7, no. 1, 3-4.

United Nations High Commissioner for Refugees (UNHCR). 1995. The State of the World's Refugees: In Search of Solutions. New York: Oxford University Press.

Vargas, Claudia Maria. 1998. "Ethical Challenges in Refugee Research: Troublesome Questions, Difficult Answeys." Refuge 17, no. $3,35-46$.

Weisbrod, Burton A. 1997. "The Future of the Nonprofit Sector: Its Entwining with Private Enterprise and Government." Journal of Policy Analysis and Management 16, no.4, 541-55.

Yau, Maria. 1996. "Refugee Students in Toronto Schools." Refuge 15, no. 5, 9-16.

Zhou, Min and Carl L. Bankston III. 1998. Growing Up American: How Vietnamese Children Adapt to Life in the United States. New York, Russell Sage Foundation. $\square$

\section{Breaking Ground:}

\section{The 1956 Hungarian Immigration to Canada}

\author{
Edited by Robert H. Keyserlingk \\ Toronto: York Lanes Press, 1993; 1SBN 1-55014-232-1; \\ 117 pages, $\$ 6.99$
}

This book is a collection of personal and archival-based memories on the selection, transport ind settement of about 40,000 Hungarian refugees in Canadh in one year. It is a source of primary record as well as scholarly reflection on one of the most significant refugee movements to Canada afier World Wart 11 - the 1956 Hungarian refugee movernent.

Bused on pepers that were presented at a 1990 conference, the authors touch on the unique political, administrative and setdenent features of this movement. The resulting work, edired by Professor Keyserlingk, is a unique mix of personal reminiscences and academic scholarship.

\section{Aratlable from:}

Cenere for Refugee Sardita

\section{Legitimate and Illegitimate Discrimination: New Issues in Migration}

\section{Edited by Howard Adelman}

Toronto: Yqdk Lanes Press, 1995; 1SBN 1-55014-238-0; 287 pages, indexed; $\$ 22.95$

Freedom of movemen, If the members of a state are forced to flee, the legitimacy of that government is questronable, On the cher hand, if members cannot or must leave, again the government is not democratically lezitimate.

Immigration control: While limiting access and determining who may or may not become members of a Eoreregat state remains a legitmate prerogative of the state, the criteria, rules and processes for doing so must be compatible with its character as a democratic state.

Legthinte ma Illegiti, te Discrimination: New Issues in Migration, edited by Professor Howard Adelman, deals with the questiof of legitimacy with cases studies from the Developing World, Europe, Australia, the United Sotes, and C. Mada.

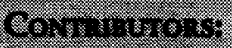

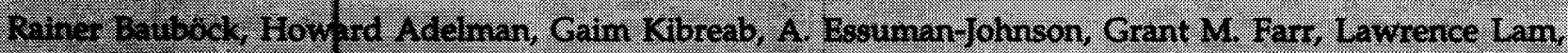

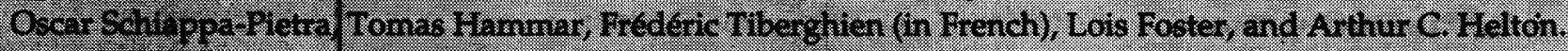

Avorlable from:

Centre for Retugee Studies

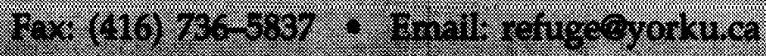




\section{REPORIS}

\section{- Somali Refugees in Toronto: A Profile}

By Edward Opoku-Dapaah, 1995

ISBN 1-55014-278-x, 130 pp., \$12.95.

This is the first comprehensive study of Somali refugees in Toronto. It examines the social, residential, and linguistic characteristic of Somalis, their participation in the local economy, and the activity of Somali community organizations. The report also contains valuable suggestions and recommendations concerning suitable and more efficient service delivery to this community.

\section{- Cambodian Refugees in Ontario: An Evaluation of Resettlement and Adaptation}

By Janet McLellan, 1995

ISBN 1-55014-267-4, 142 pp., \$12.95.

This major study of Cambodian refugees in Ontario examines the effects of various forms of sponsorship on Cambodian resettlement. It also focuses and the linguistic, economic, educational, training and social dimensions of the whole process of adaptation. The delivery of services by governmental and NGO agencies as well as the effects of the past traumatic experiences of genocide and mass starvation on Cambodian refugees are fully discussed.

\section{- Refugee Families and Children:} A Directory for Service Providers in Metro Toronto

Compiled by

John Morris and Lydia Sawicki, 1995

ISBN 1-55014-285-2,39 pp., \$6.95.

This directory is designed for service providers who work with refugee families and children in Metro Toronto. Its aim is to improve service provision through networking and the sharing of training opportunities.

Available from:

\section{Centre for Refugee Studies}

Refuge, Vol. 18, No.2 (April 1999)

\section{Back Issues of Refuge, Canada's periodical on refugees}

1. Environmental Refugees, Vol. 12, No. 1, June 1992.

2. Discussion of Immigration Bill C-86, Vol. 12, No. 2, July/(August) 1992.

3. General Issue/Refugee Sponsorship, Vol. 12, No. 3, Sept. 1992.

4. Eastern European Refugees, Vol. 12, No. 4, Oct. 1992.

5. The Tragedy of Somalia, Vol. 12, No. 5, November/December 1992.

6. The Review of Rejected Refugee Claims in Canada, Vol. 12, No. 6, January 1993.

7. Russia and Central Eurasia, Vol. 12, No. 7, February 1993.

8. Africa Issue: Repatriation, Vol. 12, No. 8, March 1993.

9. General Issue/Globalization, Vol. 13, No. 1, April 1993.

10. Russia and Central Eurasia, Vol. 13, No. 2, May 1993.

11. Special Issue on Sri Lanka, Vol. 13, No. 3, June 1993.

12. Gender Issues and Refugee Law, Vol. 13, No. 4, July/August 1993.

13. Southeast Asian Refugees, Vol. 13, No. 5, Sept. 1993.

14. Mozambican Refugees, Vol. 13, No. 6, October 1993.

15. Russia and Central Eurasia, Vol. 13, No. 7, November/December 1993.

16. General Issue/Sudan, Vol. 13, No. 8, January 1994.

17. Integration of Refugees-The Canadian Experience, Vol. 13, No. 9, February 1994.

18. Refugees and Peace in Central America, Vol. 13, No. 10, March 1994.

19. Horn of Africa, Vol. 14, No. 1, April 1994.

20. The Russian Federation, Vol. 14, No. 2, May 1994.

21. The Former Yugoslavia, Vol. 14, No. 3, June/July 1994.

22. General Issue/IRB and Rebuilding Trust/Tamil Immigrants in Canada, Vol. 14, No. 4, August/September 1994.

23. Rwandan Crisis, Vol. 14, No. 5, October 1994.

24. Refugee Resettlement in Israel, Vol. 14, No. 6, November 1994.

25. Refugee Women-Part 1: Issues, Vol. 14, No. 7, December 1994.

26. Refugee Women-Part 2: Case Studies, Vol. 14, No. 8, January 1995.

27. The Safe Third Country Concept, Vol. 14, No. 9, February 1995.

28. Special Issue on Chechnya, Vol. 14, No. 10, March 1995.

29. Reformulation of International Refugee Law, Vol. 15, No. 1, 1996.

30. Environment, Development and Refugees, Vol. 15, No. 2, 1996.

31. International Intervention in Refugee Crises, Vol. 15, No. 3, 1996.

32. Early Warning on Humanitarian Crises, Vol. 15, No. 4, 1996.

33. Child Refugees, Vol. 15, No. 5, 1996.

34. Global Settlement Services, Vol. 15, No. 6, 1997.

35. Early Warning and Early Response, Vol. 16, No. 1, May 1997.

36. Uprooting and Consequences, Vol. 16, No. 2, June 1997.

37. Development-induced Displacement, Vol. 16, No. 3, August 1997.

38. Refugee and Immigrant Women: An International Perspective, Vol. 16, No. 4, October 1997.

39. Working with Refugees and Internally Displaced Persons, Vol. 16, No. 5, Nov. 1997.

40. Conflict, Population Displacement, and Conflict Resolution, Vol. 16, No. 6, Dec. 1997.

41. Refugee and Immigrant Women: An International Perspective, Part II, Vol. 17, No. 1, February 1998.

42. Human Rights and Refugee Movements in the Newly Independent States of the Former Soviet Union, Vol. 17, No. 2, April 1998.

43. Current Issues in Refugee and Human Rights Policy and Research, Vol. 17, Nö. 3 , August 1998.

44. Violent Displacement and Post-Conflict Reconstruction: Afghanistan, Uganda, and Rwanda, Vol. 17, No. 4, October 1998.

45. New Cargo: The Global Business of Trafficking in Women, Vol. 17, No. 5, Nov. 1998.

46. Critical Perspectives on Refugees, Vol. 17, No. 6, December 1998.

47. Not Just Numbers and New Directions: Implications for Canadian Refugee Policy, Vol. 18, No. 1, February 1999.

Single copy: Vol 12, 13 \& 14-\$6.50; Vol 15, 16, 17-\$10. 10 percent discount on 3-9 issues (copies); 20 percent discount on 10 issues (copies) or more. Special discounts are available for students and exclusively volunteer-run NGOs. P. O. accepted.

Please send your orders to:

Centre for Refugee Studies, York University

Suite 333, York Lanes, 4700 Keele Street, Toronto, Ontario, Canada M3J 1P3

Fax: (416) 736-5837・Email: refuge@yorku.ca・mswinder@yorku.ca

(C) Claudia Maria Vargas, 1999. This open-access work is licensed under a Creative Commons Attribution-NonCommercial 4.0 International License, which permits use, reproduction and distribution in any medium for non-commercial purposes, provided the original author(s) are credited and the original publication in Refuge: Canada's Journal on Refugees is cited. 
Refuge

Centre for Refugee Studies

Suite 322, York Lanes York

University

4700 Keele Street, Toronto

Ontario, Canada M3J 1P3

Phone: (416) 736-5663 Fax:

(416) 736-5837 Email:

refuge@yorku.ca

\section{CALL FOR PAPERS}

\section{Humanitarian Intervention in the Wake of Kosovo Refugee Crisis}

\section{Guest Editor: Dr. Susanne SchmeidI}

This issue of Refuge, Canada's periodical on refugees, will discus the refugee crisis in Kosovo and its regional as well as international implications, with a focus on challenges to humanitarian intervention.

Topics addressed in the issue will include:

- The causes of the Kosovo crisis (politics, NATO etc.);

- Refugee expulsion and flight;

- Human security issues;

- Third-country resettlement;

- Security in refugee camps in neighbouring countries;

- Implications for regional security;

- Implication for national security such as Kosovo;

- Implications for international stability;

- Discussion of solutions such as safe zones;

- Discussion on repatriation options (or other permanent solutions), and under what circumstances; and

- Resettlement of Kosovar refugees in Canada.

Contributions with abstracts and a short biographical note about the author are invited. They should be received ASAP or no later than May31, 1999. Papers shouldbe typed, double-spaced, and referenced in the academic format. They should not exceed 16 pages or about 4000 words. Short papers of about 900 words are also welcome. Word-processed submissions may be sent on disc or by email. On accepte aussi des articles en français. Le style doit conformer aux normes exigés pour les articles rédigés en anglais.

Deadline: ASAP or no later than May 31, 1999.

For more information, please coniact:

\section{Dr. Susanne Schmeidl}

Swiss Peace Foundation, Institute for Conflict Resolution or

Gerechtigkeitsgasse 12, PO Box, $\mathrm{CH}-3000$ Bern 8

Switzerland

Tel.: $(+41-31) 310-27-31$ or $310-27-27$

Fax: $(+41-31) 310-27-28$

Email: schmeidl@swisspeace.unibe.ch
MarekSwinder, Technical Editor

Refuge (Canada's Periodical on Refugees)

Centre for Refugee Studies, York University,

Suite 333, York Lanes, 4700 Keele Street,

Toronto, Ontario, Canada M3J 1 P3

Fax: (416) 736-5837 - Tel.: (416) 736-5843

Email: mswinder@yorku.ca・refuge@yorku.ca 